\title{
Correction to: Effect of three types of liquid compost combined with Avicennia marina leaves on growth and survival of tiger prawns (Penaeus monodon)
}

\author{
Restiana Wisnu Ariyati (i) Sri Rejeki - Lestari L. Widowati • \\ Tita Elfitasari $\cdot$ Roel H. Bosma
}

Published online: 29 November 2019

(C) The Author(s) 2019

\author{
Correction to: Int Aquat Res \\ https://doi.org/10.1007/s40071-019-00239-x
}

Due to the author's omission to check the corrections by the journal' imposed reviewer of English style.

Please read the following sections and Tables as follows:

Abstract The sustainability of prawn farming in brackish water ponds is controversial because of low yields and mangrove clearing. Low yields are due mostly to insufficient preparation of pond bottoms. Mangrove trees are often planted on pond bunds as window dressing. This study examined the effect of three types of liquid compost from vegetables, fruit, and both vegetables and fruit in tanks to which whole or chopped Avicenia marina leaves were added to mimic local pond conditions. In a split-plot design, 28 square tanks were each stocked with one hundred 15-day-old post-larvae tiger prawns (Penaeus monodon). Four tanks were used as controls and 24 were assigned to the treatments, 12 with whole and 12 with chopped leaves. In both of these 12, 4 received liquid compost from vegetables, 4 from fruits and 4 from their mixture. Shrimp were weighed at the start, halfway and end of the 50-day trial, and fed at 5\% of the estimated total weight; survival was counted at the end. The survival rates of treatments and controls (65-76\%) were not significantly different. Shrimp in water with vegetable compost grew significantly faster $\left(2.7 \%\right.$ day $\left.^{-1}\right)$ than in both treatments with fruit $\left(2.5 \%\right.$ day $\left.^{-1}\right)$. Shrimp in all treatments grew significantly faster than those in the controls $\left(2.0 \%\right.$ day $\left.^{-1}\right)$. The lower growth rate of shrimp fed fruit compost may have been due to dinoflagellates, which are known to negatively affect shrimp. Shrimp in tanks with chopped leaves of $A$. marina grew slightly better than shrimp in tanks with whole leaves.

On page 3, just above 'Data collection and calculation':

"The post-larva shrimp were fed with commercial pellets at $5 \%$ of total body weight, estimated at the start and halfway the study. To encourage shrimp to use the natural feed produced in the tanks, ..."

The original article can be found online at https://doi.org/10.1007/s40071-019-00239-x.

R. W. Ariyati $(\bowtie) \cdot$ S. Rejeki $\cdot$ L. L. Widowati $\cdot$ T. Elfitasari

Aquaculture Department, Faculty of Fisheries and Marine Sciences, Diponegoro University, Semarang, Indonesia

e-mail: resti_wisnoe@yahoo.com

R. H. Bosma

Aquaculture and Fisheries Group, Wageningen University, Wageningen, The Netherlands 
Table 1 Multifactorial split-plot ANOVA on the effects of mangrove leaves and compost type on P. monodon SR

\begin{tabular}{lllll}
\hline Source of variation & $d f$ & MS & $F$ & Sig. \\
\hline Intercept & 1 & 125,778 & 7843 & 0.08 \\
Mangrove leaves type & 1 & 9.4 & 0.89 & 0.79 \\
Repetition & 4 & 32,994 & 0.61 & 0.62 \\
Liquid compost type & 2 & 211 & 1.75 & 0.22 \\
Mangrove * compost & 2 & 0.9 & 0.007 & 0.99 \\
\hline
\end{tabular}

Table 2 Multifactorial split-plot ANOVA on the effects of mangrove leaves and compost type on $P$. monodon SGR

\begin{tabular}{lcllr}
\hline Source of variation & $d f$ & MS & $F$ & Sig. \\
\hline Intercept & 1 & 84.8 & 16,737 & $\mathbf{0 . 0 0}$ \\
Mangrove leaves type & 1 & 1.04 & 28.8 & $\mathbf{0 . 0 1}$ \\
Repetition & 4 & 0.01 & 0.16 & 0.95 \\
Compost type & 12 & 0.73 & 32.5 & $\mathbf{0 . 0 0}$ \\
Mangrove * compost & 12 & 0.01 & 0.20 & 0.82 \\
\hline
\end{tabular}

Table 5 Plankton species counts in the water of the six treatments and the indexes for plankton diversity, uniformity, and dominance

\begin{tabular}{|c|c|c|c|c|c|c|}
\hline Plankton & A1B1 & A1B2 & A1B3 & $\mathrm{A} 2 \mathrm{~B} 1$ & $\mathrm{~A} 2 \mathrm{~B} 2$ & A2B3 \\
\hline Total count $\left(\mathrm{n} \mathrm{mL} \mathrm{L}^{-1}\right)$ & 7498 & 8941 & 12,688 & 8651 & 9517 & 11,823 \\
\hline \multicolumn{7}{|l|}{ Bacillariophyceae } \\
\hline Rhizosolenia sp. & 865 & 2019 & 1730 & 865 & 2019 & 2019 \\
\hline Pleurosygma sp. & 577 & 865 & 3749 & 2019 & 1442 & 3749 \\
\hline Synedra sp. & 2019 & 2019 & 2019 & 1442 & 1730 & 2307 \\
\hline Thalassiotrix sp. & 577 & 577 & - & - & - & - \\
\hline Coscinoduscus sp. & 1153 & 1442 & 1153 & 1442 & 1442 & 865 \\
\hline Guinardia sp. & - & - & 1442 & - & - & - \\
\hline Nitzschia sp. & - & - & - & 288 & 865 & 1153 \\
\hline \multicolumn{7}{|l|}{ Dinophyceae } \\
\hline Ceratium sp. & 577 & - & - & 288 & - & - \\
\hline Peridinium sp. & - & - & 865 & 288 & - & 577 \\
\hline \multicolumn{7}{|l|}{ Cyanophyceae } \\
\hline Oscillatoria sp. & 1730 & 2019 & 1730 & 2019 & 2019 & 1153 \\
\hline Diversity index $H^{\prime}$ & 1.44 & 1.59 & 1.90 & 1.58 & 1.59 & 1.78 \\
\hline Uniformity index $e^{\prime}$ & 0.69 & 0.77 & 0.92 & 0.76 & 0.76 & 0.85 \\
\hline Domination index $D$ & 0.07 & 0.11 & 0.20 & 0.10 & 0.11 & 0.19 \\
\hline
\end{tabular}

Acknowledgements We heartily appreciate the Faculty of Fisheries and Marine Sciences, University of Diponegoro, for contributing to this research through NON-APBN Research Grant no. 2300/UN.7.3.10/LT/2017. We acknowledge the PASMI project, funded mainly by NWO-WOTRO (Grant No. W 08.260 .303 ), for providing the water quality measurement equipment and the cultivation facilities we used in this study. Our thanks goes also to Dr Lorna Mira Calumpang for reviewing the English grammar and style, and to all our colleagues who assisted us in conducting this research until its completion.

Open Access This article is distributed under the terms of the Creative Commons Attribution 4.0 International License (http:// creativecommons.org/licenses/by/4.0/), which permits unrestricted use, distribution, and reproduction in any medium, provided you give appropriate credit to the original author(s) and the source, provide a link to the Creative Commons license, and indicate if changes were made. 